\title{
Front Matter: Volume 11488
}

, "Front Matter: Volume 11488," Proc. SPIE 11488, Optical System Alignment, Tolerancing, and Verification XIII, 1148801 (15 September 2020); doi: $10.1117 / 12.2581579$

SPIE. Event: SPIE Optical Engineering + Applications, 2020, Online Only 


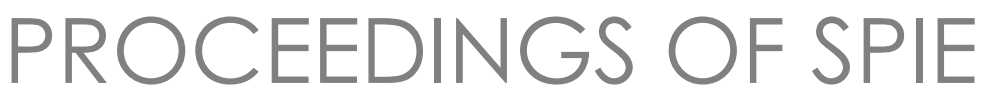

\section{Optical System Alignment, Tolerancing, and Verification XIII}

José Sasián

Richard N. Youngworth

Editors

24 August - 4 September 2020

Online Only, United States

Sponsored and Published by

SPIE 
The papers in this volume were part of the technical conference cited on the cover and title page. Papers were selected and subject to review by the editors and conference program committee. Some conference presentations may not be available for publication. Additional papers and presentation recordings may be available online in the SPIE Digital Library at SPIEDigitalLibrary.org.

The papers reflect the work and thoughts of the authors and are published herein as submitted. The publisher is not responsible for the validity of the information or for any outcomes resulting from reliance thereon.

Please use the following format to cite material from these proceedings:

Author(s), "Title of Paper," in Optical System Alignment, Tolerancing, and Verification XIII, edited by José Sasián, Richard N. Youngworth, Proceedings of SPIE Vol. 11488 (SPIE, Bellingham, WA, 2020) Seven-digit Article CID Number.

ISSN: 0277-786X

ISSN: 1996-756X (electronic)

ISBN: 9781510637825

ISBN: 9781510637832 (electronic)

Published by

SPIE

P.O. Box 10, Bellingham, Washington 98227-0010 USA

Telephone +1 3606763290 (Pacific Time) · Fax +1 3606471445

SPIE.org

Copyright (c) 2020, Society of Photo-Optical Instrumentation Engineers.

Copying of material in this book for internal or personal use, or for the internal or personal use of specific clients, beyond the fair use provisions granted by the U.S. Copyright Law is authorized by SPIE subject to payment of copying fees. The Transactional Reporting Service base fee for this volume is $\$ 21.00$ per article (or portion thereof), which should be paid directly to the Copyright Clearance Center (CCC), 222 Rosewood Drive, Danvers, MA 01923. Payment may also be made electronically through CCC Online at copyright.com. Other copying for republication, resale, advertising or promotion, or any form of systematic or multiple reproduction of any material in this book is prohibited except with permission in writing from the publisher. The CCC fee code is $0277-$ $786 \mathrm{X} / 20 / \$ 21.00$.

Printed in the United States of America by Curran Associates, Inc., under license from SPIE.

Publication of record for individual papers is online in the SPIE Digital Library.

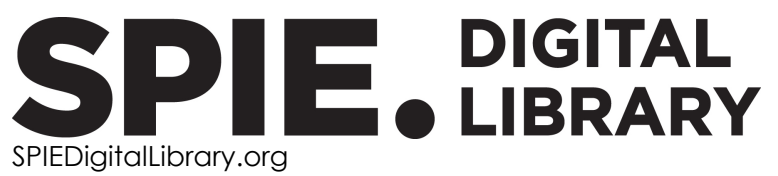

Paper Numbering: Proceedings of SPIE follow an e-First publication model. A unique citation identifier (CID) number is assigned to each article at the time of publication. Utilization of CIDs allows articles to be fully citable as soon as they are published online, and connects the same identifier to all online and print versions of the publication. SPIE uses a seven-digit CID article numbering system structured as follows:

- The first five digits correspond to the SPIE volume number.

- The last two digits indicate publication order within the volume using a Base 36 numbering system employing both numerals and letters. These two-number sets start with $00,01,02,03,04$, 05, 06, 07, 08, 09, OA, OB ... 0Z, followed by 10-1Z, 20-2Z, etc. The CID Number appears on each page of the manuscript. 


\section{Contents}

\section{VERIFICATION AND ALIGNMENT}

1148804 An approach to upgrading the beam transport system at the Navy Precision Optical Interferometer [1 1488-2]

$1148805 \quad$ Verification of the optical system of the 9.7- $\mathrm{m}$ prototype Schwarzschild-Couder Telescope [1 1488-3]

1148806 Linearization of defocus for projector optical alignment in structured light illumination systems [11488-4]

1148807 Practical measurement of cell-phone camera lens focal length [1 1488-5]

TOLERANCING AND ALIGNMENT

1148808 Study of tolerancing optimization approaches in Zemax for as-built performance [1 1488-6]

1148809 Sensitivity analysis of the CTE and thermo-optical coefficients of a passively athermalized lens [11488-7]

11488 OA Tolerance eigenmodes of optical systems (Invited Paper) [1 1488-8]

11488 OB Recent developments in tolerancing methods for imaging spectrometers [11488-9]

11488 OC Exact wavefront refracted through cemented doublet lenses [11488-10]

\section{ALIGNMENT AND METHODS I}

$11488 \mathrm{OF} \quad$ Adapting a prototype zoom lens to work outside its zoom range [11488-13]

$114880 G$ Using spherical aberration as a tool in aligning off-axis aspheric mirrors, as described in "Introduction to Optical Alignment Techniques", a short course long offered through SPIE [11488-14] 
ALIGNMENT AND METHODS II

11488 Ol Alignment and verification testing of the GPS LRA test bed [1 1488-16]

$114880 \mathrm{~J} \quad$ Aligning reflecting optics with Bessel beams [1 1488-17]

11488 OK Hartmann testing and vibration for RST (WFIRST) [1 1488-18]

11488 OL Data analysis algorithm for double-pass testing of the Roman Space Telescope [11488-19]

POSTER SESSION

1148800 Development of a vacuum-compatible manipulator to calibrate wide field UV imagers for Cubesats [1 1488-22]

11488 OP Optical characterization of electro-optics lenses for researching in optics [11488-23]

$114880 Q \quad$ Wavelength detection method using vortices [11488-24] 